\title{
HPLC-measured chlorophyll-type pigments during a phytoplankton spring bloom in Bedford Basin (Canada)
}

\author{
Suzanne Roy \\ Department of Oceanography, Dalhousie University, Halifax, Nova Scotia, Canada B3H 4J1 \\ and \\ INRS-Océanologie, 310 Allée des Ursulines, Rimouski, Québec, Canada G5L 3A1 •
}

\begin{abstract}
Composition of HPLC-analysed chlorophyll pigments was followed during the phytoplankton spring bloom in 1984 in Bedford Basin (Nova Scotia, Canada). Pigment distribution characterized 3 different bloom stages: high concentration and relative proportion of chl $a$ in the early bloom stage, increasing importance of chl a derivatives and pheopigments (both pheophytin a and pheophorbide a) in the late bloom stage, and, after a mixing event, transport of surface pigments to the deeper layers, followed by an increase in pheopigments. These results can be interpreted as a combination of changing physiological condition, grazing and vertical transport. Processes affecting pigment distribution are discussed and it is suggested that a number of pigment-affecting processes be better identified before pigment indicators are to be used quantitatively.
\end{abstract}

\section{INTRODUCTION}

Phytoplankton spring blooms have attracted much interest because they are a well-defined seasonally recurrent event. These blooms are characterized by a period of intensive growth, followed by a decay caused by factors such as nutrient limitation (Fogg 1965), which subsequently results in intensive sedimentation (Smetacek et al. 1978). During the time-course of the bloom, one can examine the effects of changing chemical environment, changing physiological condition of the cells and transformations during sedimentation of the bloom.

Chlorophyll-type pigments, particularly chlorophyll (chl) a, are often used to follow biomass changes during blooms (Riley 1943, Platt \& Subba Rao 1970, Hitchcock. \& Smayda 1977). Models have been proposed where phytoplankton growth, macrozooplankton and microzooplankton grazing, sedimentation, photodegradation and cell senescence could be described with simple measurements of total (not chromatographically isolated) chlorophyll and pheopigments (SooHoo \& Kiefer 1982a, b, Welschmeyer \& Lorenzen 1985). However,

\footnotetext{
- Address for reprint requests
}

relatively few studies have looked at how each of these pigments evolves throughout a bloom. The appearance of chl a derivatives marked bloom decline in the studies of Jensen \& Sakshaug (1973) and Hallegraeff (1977. 1981), while an increase in the proportion of chlorophyllide a characterized bloom senescence in the studies of Gowen et al. (1983) and Ridout \& Morris $(1985,1988)$. Sedimentation following a bloom resulted in an increase in the proportion of pigments other than chl a, particularly pheopigments (Lorenzen 1967, Billett et al. 1983, Malone et al. 1983). An increase in the sum of chla derivatives was also noted at the end of a diatom bloom in coastal waters (Klein \& Sournia 1987).

Considering the growing recognition that appearance or changes in particular pigments may be used as biological indicators (Sakshaug 1980), the distribution of individual chlorophyll-type pigments was studied during a spring bloom event. The sampling site, Bedford Basin (Nova Scotia, Canada), generally undergoes phytoplankton blooms in spring time (Platt \& Subba Rao 1970, Conover 1975, Smith et al. 1983, Parrish 1987). The March 1984 phytoplankton spring bloom was followed at different depths, and HPLC-analyzed pigments were determined concurrent with environmental parameters. Three principal objectives were pursued: (1) describe chloropigment transformations during a 
bloom, (2) investigate depth-related changes in pigments consequent upon sedimentation of the bloom, and (3) attempt to identify the most important processes influencing the distribution of chloropigments.

\section{MATERIALS AND METHODS}

Sampling was carried out twice a week from 23 February to 26 March 1984 at a central location ('Compass Buoy') of Bedford Basin, a $70 \mathrm{~m}$ deep, $17 \mathrm{~km}^{2}$ steepsided marine basin in Nova Scotia, Canada. Seawater from 5 depths $(1,5,15,35$ and $55 \mathrm{~m})$ was routinely collected around noon local time with 51 Go-Flo bottles. Filtrations were done immediately, using Whatman $\mathrm{GF} / \mathrm{F}$ filters, after prefiltration through $200 \mu \mathrm{m}$ mesh to remove large zooplankton. Volumes filtered varied between 0.4 and 0.61 . Filters were frozen $\left(-20^{\circ} \mathrm{C}\right)$ until analysis, and duplicate samples from each filtrate were also kept frozen for nutrient analysis. The filters were used for particulate carbon $(\mathrm{C})$, nitrogen $(N)$, and pigment analysis. Total pigments were measured with the fluorometric technique (Yentsch \& Menzel 1963, HolmHansen et al. 1965); details of their composition were obtained with high performance liquid chromatography (HPLC, see below). In situ fluorescence profiles were also taken on some occasions using a Turner Designs fluorometer. Other variables measured include temperature, salinity and Secchi depth. Temperature and salinity depth profiles were obtained using a Beckman RS5-3 electrodeless induction salinometer. Instrument malfunction prevented the use of the temperature data but salinity values were obtained by calibration against backup samples, analyzed on a Guildline Autosal model 8400 salinometer. Nitrate, nitrite, phosphate and silicate were analyzed on a Technicon Auto-Analyzer ca 1 mo after collection, using methods described in Strickland \& Parsons (1972). Particulate carbon and nitrogen were analyzed on a Perkin-Elmer CHN analyzer model 240B, using cyclohexanone-2:4-dinitrophenylhydrazone as standard. Phytoplankton species observations were carried out on a few selected Lugolpreserved samples, using an inverted microscope (Utermöhl 1931). The ${ }^{14} \mathrm{C}$ uptake method (Strickland \& Parsons 1972) was used for in situ productivity measurements. Incubations of $2 \mathrm{~h}(12: 00$ to $14: 00 \mathrm{~h})$ were carried out at the various sampling depths in $150 \mathrm{ml}$ glass bottles (2 light, 1 dark) inoculated with $1 \mathrm{ml}$ of $\mathrm{NaH}^{14} \mathrm{CO}_{3}$ solution $\left(1.89 \times 10^{5} \mathrm{~Bq} \mathrm{ml}^{-1}\right)$. After incubation, bottle contents were filtered on Gelman AE filters which were acid-fumed and put in scintillation liquid (BDH code R04697). The samples were counted in a LKB 1215 Rackbeta instrument and quench-corrected by the channels-ratio method (Kobayashi \& Maudsley 1969).
Pigment analysis. Chlorophyll pigments were analyzed by HPLC analysis, using Mantoura \& Llewellyn's (1983) ion-pairing technique. Filters were extracted in cold $\left(0\right.$ to $\left.5^{\circ} \mathrm{C}\right)$ absolute acetone to reduce the action of the enzyme chlorophyllase (Barrett \& Jeffrey 1971). Filters were ground by hand using a glass rod - this was found as efficient and more convenient than mechanical grinding. Extracts were then filtered on Whatman GF/F filters and 50 to $100 \mu$ volumes were injected into a RP-C18 Hypersil column. Pigments were separated by gradient elution as in Mantoura \& Llewellyn (1983), except that flow rate was initially $1.5 \mathrm{ml}$ $\min ^{-1}$ (Varian 5000 pumping system) and that a guard column was used. Detection was done fluorometrically using a Schoeffel FS970 instrument with excitation set at $430 \mathrm{~nm}$ and emission $>580 \mathrm{~nm}$. A Hewlett Packard HP3390A integrator monitored the output from the fluorometer and calculated pigment concentrations by comparison with standards. The linearity in fluorescence for chl a was verified up to $154 \mathrm{ng}$. The lowest chl a detection level was $0.5 \mathrm{ng}$ in absolute weight, or $50 \mathrm{ng} \mathrm{l^{-1 }}$ for a $100 \mu$ injection of a $10 \mathrm{ml}$ extract from $1 \mathrm{l}$ of seawater. Concentrations are expressed as femto (f or $10^{-15}$ ) moles of pigment per litre. Pigment standards came from various sources: chl $a$ and $b$ were obtained from Sigma Chemical Company, chlc was extracted from the diatom Phaeodactylum tricornutum, isolated using the TLC procedure of Jeffrey (1981), chlorophyllide a was extracted from commercial spinach leaves by the method of Barrett \& Jefrey (1971), followed by isolation with TLC (Jeffrey 1981), and the pheophytins and pheophorbides were prepared from their respective chlorophylls and chlorophyllides by weak acidification. Concentration of these standards was measured on a Cary 14 spectrophotometer, using the specific absorption coefficients of Brown (1968) and, for chl $c_{\text {, }}$ of Lorenzen \& Jeffrey (1980). The whole procedure, from extraction to HPLC injection, accounted for a maximum loss of $3 \%$ chla (internal standard addition), and replicate injections of standards over a 2 wh period gave coefficients of variation of $1.7 \%$ for chl $a, 8.4 \%$ for chl $c$ and $17 \%$ for pheophytina

\section{RESULTS}

\section{Physico-chemical environment}

Sea surface temperature, measured with a thermometer, varied little $\left(0\right.$ to $\left.3^{\circ} \mathrm{C}\right)$. Changes in water density were thus related to changes in salinity The salinity profile (Fig. 1) characterized 3 periods: (1) from 27 February to 10 March, a time of relative stability with a strong gradient in salinity; (2) from 10 to 
17 March, breakdown of the density stratification as illustrated by vertical isohalines; and (3) from 17 to 26 March, a salinity gradient forming again after reestablishment of stable conditions. Period (2) was also characterized by higher than average winds: values above $25 \mathrm{~km} \mathrm{~h}^{-1}$ were recorded on 10,14 and 15 March (Environment Canada 1984). On these last $2 \mathrm{~d}$, and especially on 14 March when winds reached an average speed of $35.5 \mathrm{~km} \mathrm{~h}^{-1}$, the prevailing wind direction was ESE, along the longest dimension of the basin, promoting mixing (Côté \& Platt 1983).

The distribution of nitrate (Fig. 2) can also be divided into 3 periods. In the first, nitrates were strongly stratified with low values in surface water. In the second, a more homogeneous distribution was observed, with values around 3 to $4 \mu M$ extending from surface to $35 \mathrm{~m}$. In the third, a nutricline was slowly re-established. The distributions of phosphate and silicate were similar to that of nitrate (Roy 1986).

Solar radiation, expressed as the number of hours of bright sunshine insolation measured at Shearwater, $15 \mathrm{~km}$ from the sampling station (Environment Canada 1984), showed highest values between 1 and 13 March, mostly associated with the first period (Table 1). Secchi disk readings were used to calculate extinction coefficients $(\mathrm{k}=1.44 /$ Secchi depth; Holmes 1970) and are also given in Table 1 . Highest values were obtained during Period (1).

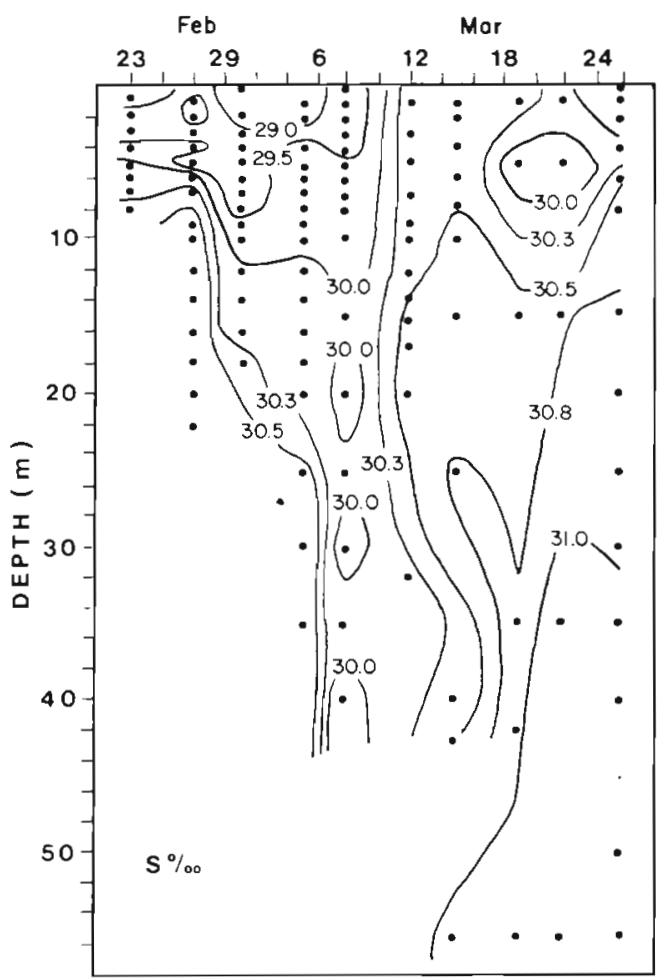

Fig. 1. Salinity profile for the period $23 \mathrm{Feb}$ to $26 \mathrm{Mar} 1984$ in Bedford Basin

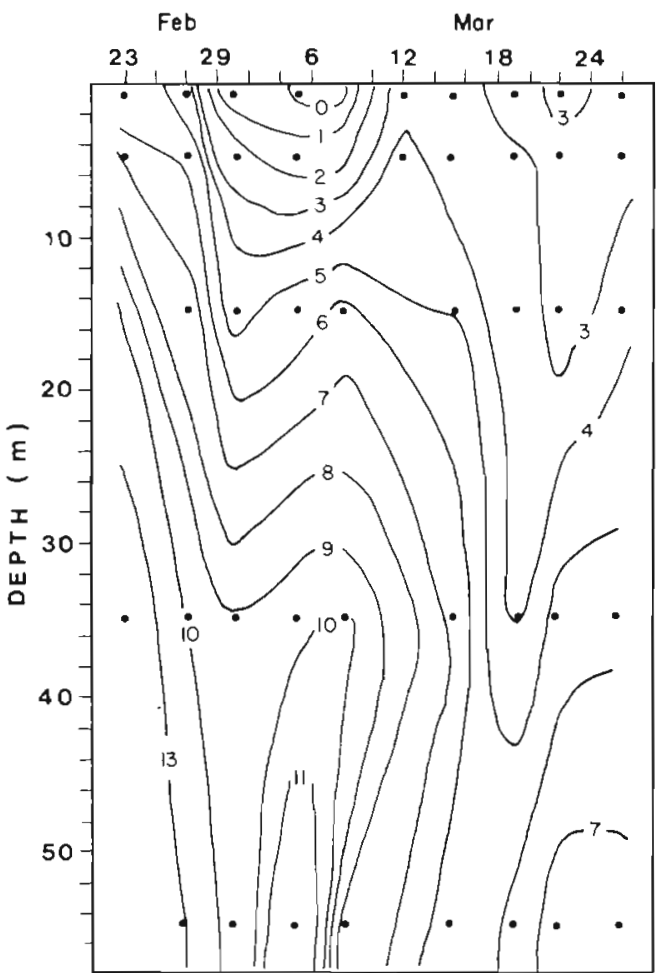

Fig. 2. Contour plot of nitrates $(\mu M)$ for the period 23 Feb to 26 Mar 1984 in Bedford Basin

\section{Phytoplankton species and productivity}

Taxonomic observations revealed the presence of a few species of diatoms during the bloom period, including Chaetoceros septentrionalis, Thalassiosira nordenskioldii and Skeletonema costatum. C. septentrionalis dominated the phytoplankton assemblages with $34 \times 10^{5}$ cells $l^{-1}$ ( $65 \%$ of total cells) on 5 March at $5 \mathrm{~m}$. It is a well-known component of the spring bloom flora in this basin (Platt et al. 1973). This species was also dominant at depth during the bloom decline (see

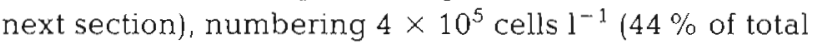
cells) on 19 March at $35 \mathrm{~m}$. It was, however, not present at $55 \mathrm{~m}$ on 1 March (Roy 1986).

Phytoplankton production, expressed as ${ }^{14} \mathrm{C}$ uptake, was measured on 1, 8 and 15 March at the 5 sampling depths. Results (Table 2) show highest values at surface on 8 March, both in terms of total $\left(30.9 \mathrm{mg} \mathrm{C} \mathrm{m}^{-3}\right.$ $\mathrm{h}^{-1}$ ) and specific (7.2 $\mathrm{mg} \mathrm{C} \mathrm{mg} \mathrm{chl} \mathrm{a}^{-1} \mathrm{~h}^{-1}$ ) productivity.

\section{HPLC-determined chlorophyll pigments}

A variety of chlorophyll pigments was found during this study: chl $a$, chl $c$, chl $b$, chlorophyllide $a$, chl $a$ allomers, chl $a^{\prime}$-like (isomer), pheophytin a, a pheophytin a-like pigment (less polar), pheophorbide $a$ and a pheophorbide a-like pigment (less polar). A representa- 
Table 1. Solar radiation and extinction coefficient ( $k$ ) for Bedford Basin in March 1984. Solar radiation, expressed as the number of hours of bright sunshine, was provided from the Shearwater meteorological station (Environment Canada 1984), $15 \mathrm{~km}$ away from the sampling site. Extinction coefficient was calculated from Secchi disk readings as $\mathrm{k}=1.44 /$ Secchi depth (Holmes 1970)

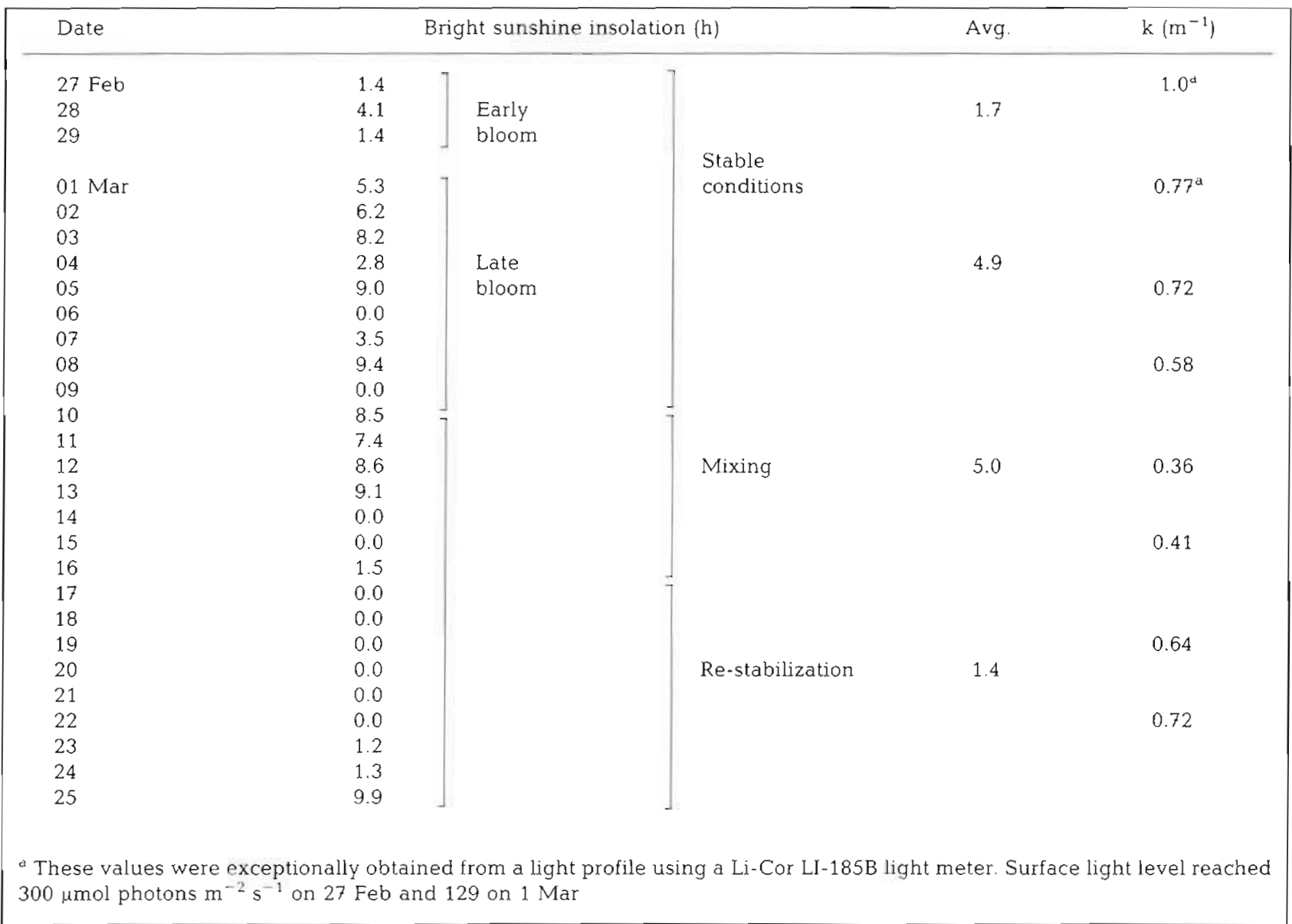

Table 2. Primary production $\left({ }^{14} \mathrm{C}\right.$ uptake) and associated carbon (C), chl a and the ratios $\mathrm{P}: \mathrm{B}$ (production : biomass), $\mathrm{C}: \mathrm{chl} a$ and C. N during the 1984 Bedford Basin spring bloom

\begin{tabular}{|c|c|c|c|c|c|c|c|}
\hline Date & $\begin{array}{l}\text { Depth } \\
(\mathrm{m})\end{array}$ & $\begin{array}{l}{ }^{14} \mathrm{CProd} \\
\left(\mathrm{mg} \mathrm{C} \mathrm{m} \mathrm{m}^{-3} \mathrm{~h}^{-1}\right)\end{array}$ & $\begin{array}{c}\mathrm{Chla} \\
\left(\mathrm{mg} \mathrm{m}^{-3}\right)\end{array}$ & $\begin{array}{c}\mathrm{P}: \mathrm{B} \\
\left(\mathrm{mg} \mathrm{C} m \mathrm{mg} \mathrm{chl} a^{-1} h^{-1}\right)\end{array}$ & $\frac{C}{\left(\mathrm{mg} \mathrm{m}^{-3}\right)}$ & $\begin{array}{c}\mathrm{C}: \mathrm{chl} a \\
\left\{\mathrm{mg} \mathrm{C} m \mathrm{mg} \mathrm{chl} a^{-1}\right\}\end{array}$ & $\begin{array}{c}\mathrm{C} . \mathrm{N} \\
\text { (atomic) }\end{array}$ \\
\hline \multirow[t]{5}{*}{$1 \mathrm{Mar}$} & 1 & 8.5 & 8.4 & 1.0 & 570 & 68 & 5.4 \\
\hline & 5 & 2.0 & 6.5 & 0.3 & 671 & 103 & 6.9 \\
\hline & 15 & 0.1 & 1.2 & 0.1 & 408 & 340 & 9.4 \\
\hline & 35 & 0 & 0.1 & 0 & 202 & 2020 & 6.9 \\
\hline & 55 & 0 & 0.1 & 0 & 107 & 1070 & 4.5 \\
\hline \multirow[t]{5}{*}{$8 \mathrm{Mar}$} & 1 & 30.9 & 4.3 & 7.2 & 744 & 173 & 8.8 \\
\hline & 5 & 6.5 & 6.4 & 1.0 & 1746 & 273 & 8.5 \\
\hline & 15 & 0.1 & 1.1 & 0.1 & 165 & 150 & 7.2 \\
\hline & 35 & 0 & 0.1 & 0 & 82 & 820 & 11.5 \\
\hline & 55 & 0 & 0.3 & 0 & 121 & 403 & 3.6 \\
\hline \multirow[t]{5}{*}{$15 \mathrm{Mar}$} & 1 & 9.4 & 2.9 & 3.2 & 467 & 161 & 10.0 \\
\hline & 5 & 2.6 & 4.2 & 0.6 & 469 & 112 & 6.8 \\
\hline & 15 & 0.3 & 1.9 & 0.1 & 333 & 175 & 8.3 \\
\hline & 35 & 0 & 0.7 & 0 & 77 & 110 & 8.4 \\
\hline & 55 & 0 & 0.9 & 0 & 115 & 128 & 7.6 \\
\hline
\end{tabular}


tive chromatogram illustrates the HPLC separation of these pigments (Fig. 3). The suffix '-like' indicates incomplete chemical characterization (SCOR/UNESCO Working Group 78, 'Determination of photosynthetic pigments in sea water', 1986: unpublished recommendation). Chl a allomers include 3 closely related chl a derivatives which appear just before the chl a peak on the chromatograms (slightly more polar). The closest to the chl a peak is the main pigment of this group, with the other 2 fractions appearing only occasionally and at very low concentrations. No formal identification of these peaks was attempted: they were assigned the name 'chl a allomers' by comparison of their chromatographic position with that of identified chl a allomers in other studies (Daley et al. 1973).

Some pigments were present only in rare occurrences: chl $b$ showed up at very low concentration $(0.1 \mathrm{nM})$ in surface waters in early March (Fig. 4), chlorophyllide a was detected at $1 \mathrm{~m}$ on 27 February, 1 , 5 and 8 March (0.2 to $0.9 \mathrm{nM}$; Fig. 4) and chl $a^{\prime}$-like was observed at $35 \mathrm{~m}$ on 1, 5 and 22 March (0.1 nMi Fig. 5).
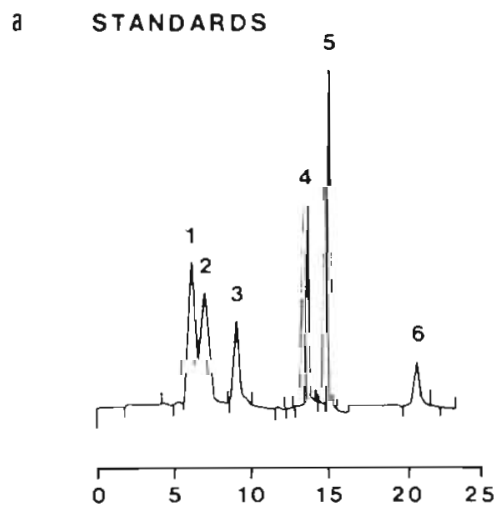

b
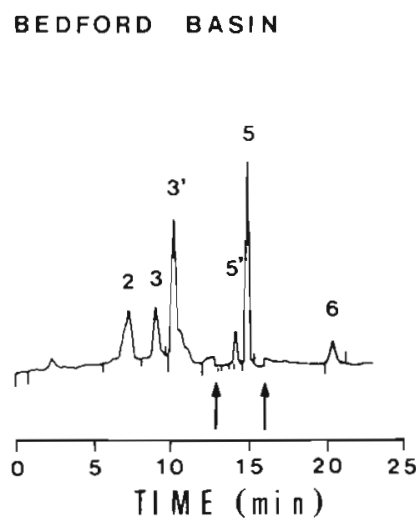

Fig. 3. HPLC chromatograms from (a) 6 pigment standards, and (b) Bedford Basin, $27 \mathrm{Feb}, 1 \mathrm{~m}$ sample. Technical details in the text. Ordinate $=$ relative fluorescence response. Abscissa $=$ time in min. Peak identification: (1) chlorophyllide $a$, (2) chl $c$, (3) pheophorbide $a_{\text {, }}\left(3^{\prime}\right)$ pheophorbide $a$-like, (4) chl $b$, (5) chl $a,\left(5^{\prime}\right)$ chl a allomer, (6) pheophytin a. Arrows indicate a change in attenuation of the fluorescence signal
The distribution of dominant pigments is shown in Fig. 4 for each of the 5 sampling depths. The chosen depths appear to adequately describe the water column characteristics when pigment results are compared to in situ fluorescence profiles (Roy unpubl.). Chl a, with the highest concentration, illustrates the

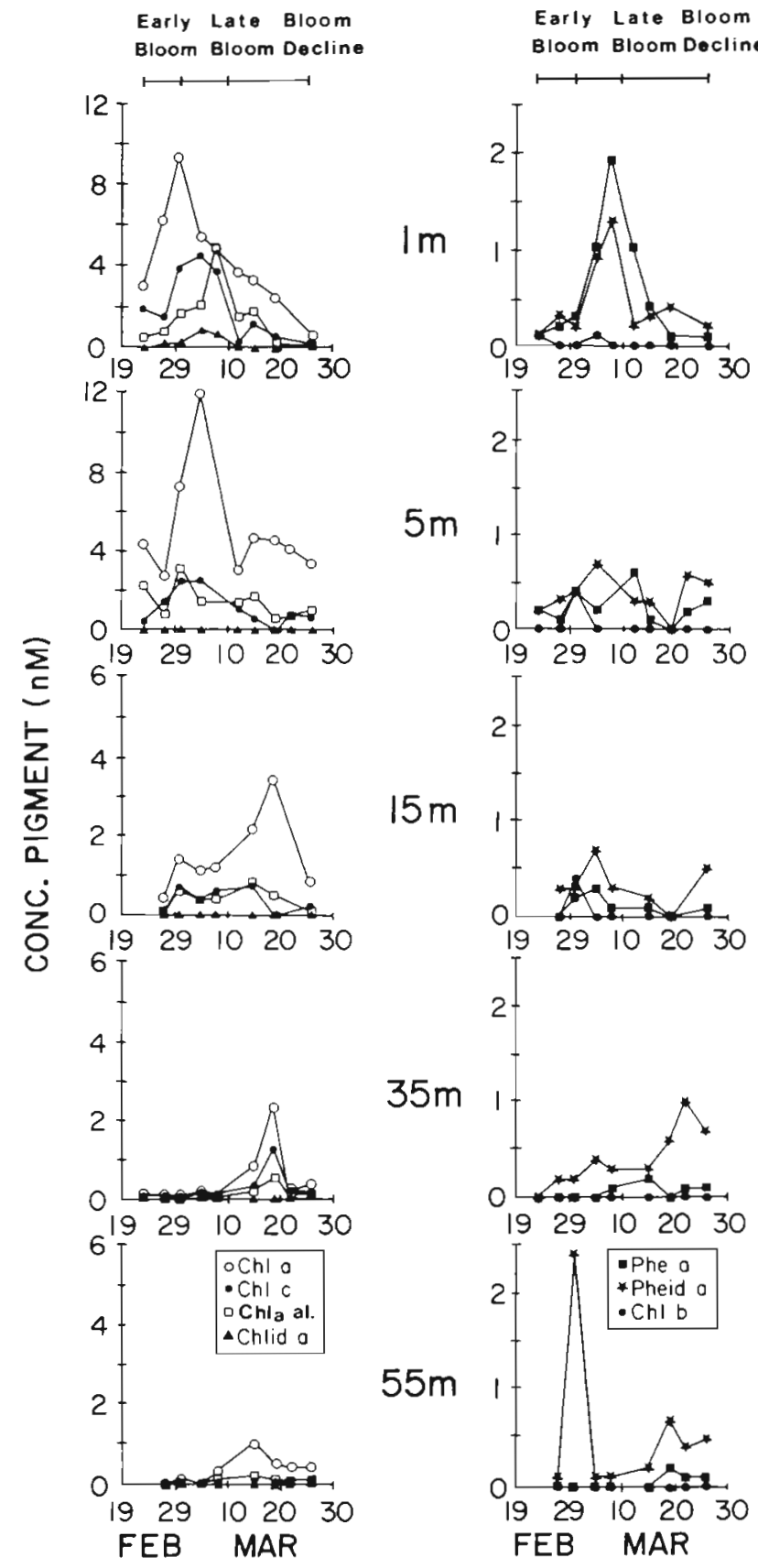

Fig. 4. Temporal distribution of the molar concentration (nM) of the various chloropigments measured at the 5 sampled depths during the 1984 spring bloom in Bedford Basin. chl: chlorophyll; chl a al.: chlorophyll a allomers; Chlid: chlorophyllide; Phe: sum of pheophytins; Pheid: sum of pheophorbides 

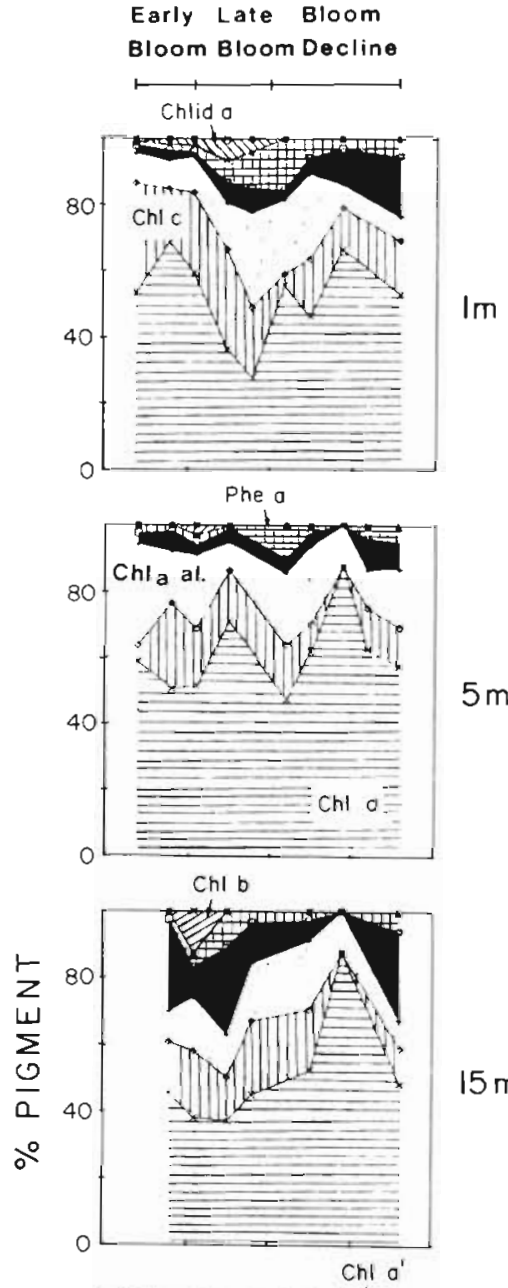

$15 \mathrm{~m}$

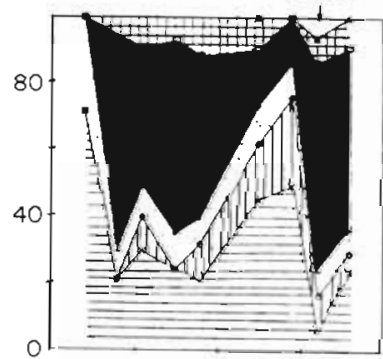

$35 \mathrm{~m}$

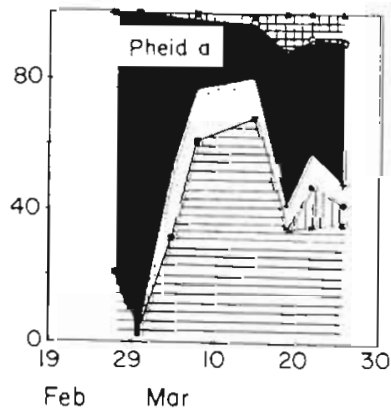

$55 m$

Fig. 5. Cumulative pigment proportions for each of the 5 sampling depths in Bedford Basin, spring 1984. Pigment name abbreviations as in Fig. 4 development of the surface bloom and its deepening after 10 March. Three periods can be identified: early bloom, late bloom and bloom decline. The early and late bloom occurred during Period (1) as defined in the physico-chemical section

Early bloom

The period from 27 February to 1 March was characterized by an increase in surface pigment values, reaching a maximum in chl a concentration by the beginning of March (9.4 $\mathrm{nM}$ on 1 March). Relative to other pigments, chl a represented ca $60 \%$ of total pigments (Fig. 5). Chl $C$ was the main accessory chlorophyll and, together with chl a allomers, showed an increase during that time, but the maxima of these did not coincide with that of chl a. In the deeper layer of Bedford Basin, concentrations of pigments were much lower ( $<3 \mathrm{nM}$ below $15 \mathrm{~m}$ ). Chlorophyll-type pigments disappeared faster with depth than pheopigments, resulting in an increase in the relative proportion of the latter (Fig. 5). The concentration of the pheophorbide a-like pigment remained generally below $1 \mathrm{nM}$ at 35 and $55 \mathrm{~m}$, except for $1 \mathrm{March}$, at $55 \mathrm{~m}$, where it reached $2.4 \mathrm{nM}$ (Fig. 6).

\section{Late bloom}

Surface concentration of chl a decreased strongly during this period ( 1 to 10 March). At $5 \mathrm{~m}$, values increased up to $11.9 \mathrm{nM}$ on $5 \mathrm{March}$, then decreased. Sampling on 8 March, done at $3 \mathrm{~m}$, follows this trend with a chl a concentration of $7.1 \mathrm{nM}$ (not shown in Fig. 4). During this period, chl $c$ first reached a maximum, then decreased, and chl a allomers continued to increase at $1 \mathrm{~m}$, reaching a maximum on 8 March (4.9 $\mathrm{n} M$ ), while their concentration at $5 \mathrm{~m}$ remained constant (Fig. 4). Chlorophyllide a appeared for the first time, culminating on $5 \mathrm{March}$ at $1 \mathrm{~m}$. It was absent from all other depths and its concentration at $1 \mathrm{~m}$ was very low $(<1 \mathrm{nM})$. Pheopigments, which were of little importance during the early bloom period, showed a distinct increase, especially at $1 \mathrm{~m}$. Pheophorbide $a$ type pigment, pheophorbide a and pheophytin a all rose in concentration from 1 to $8 \mathrm{March}$. In general, at depth, pheophorbide was more abundant than pheophytin. Pheophytin a was present in larger concentration than the pheophytin a-like pigment at 1 and $5 \mathrm{~m}$, but, as its concentration decreased faster with depth, the 2 pigments reached about equally low values in the bottom layer (Fig. 6). In the surface layer, pheophorbide a appeared at about the same concentration as the pheophorbide a-like pigment. At depth, 

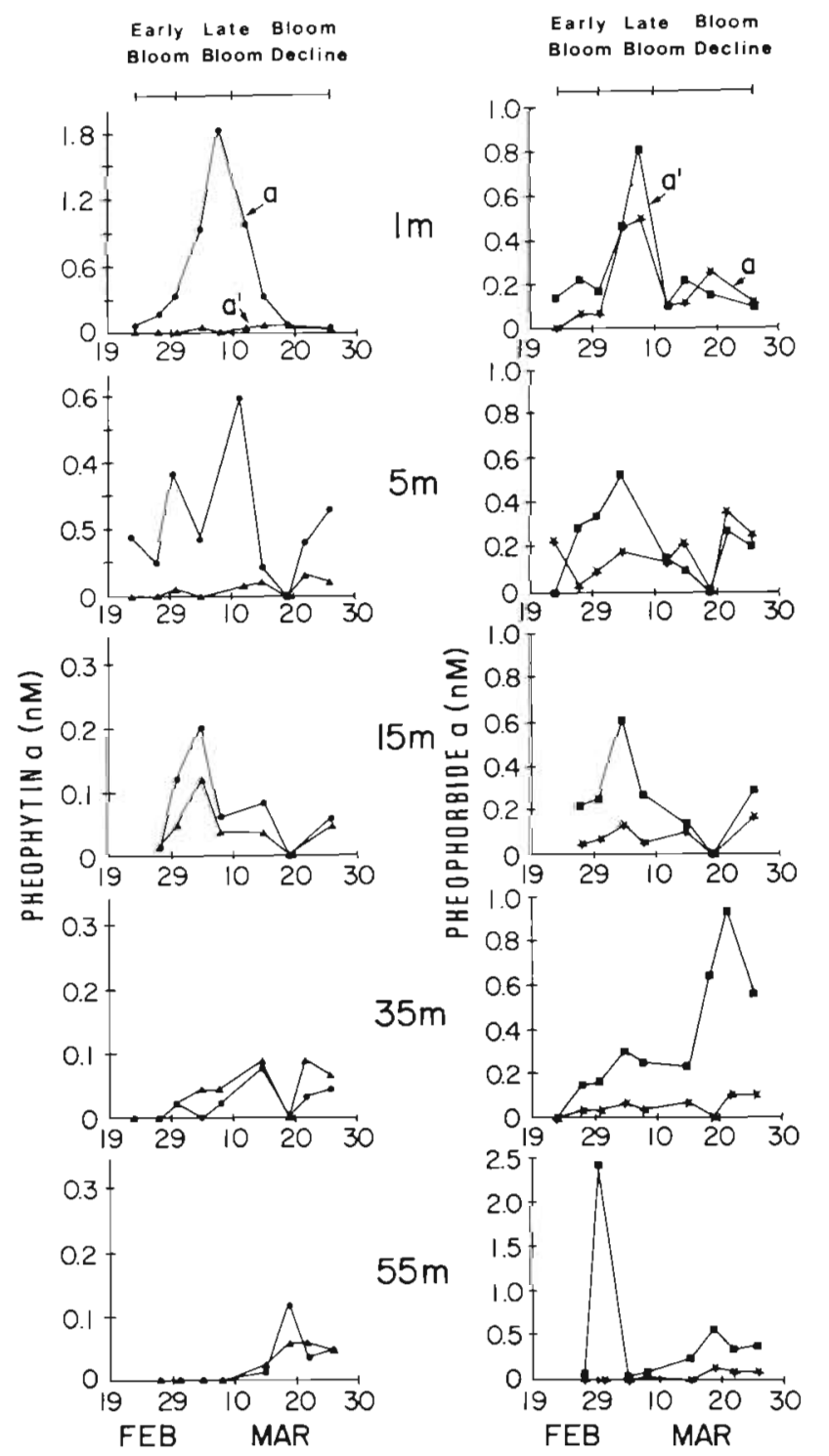

Fig. 6. Temporal distribution of the molar concentration ( $\mathrm{n} M$ ) of pheophytin $a$ and $a$-like $\left(a^{\prime}\right)$, and of pheophorbide $a$ and $a$ like ( $\left.a^{\prime}\right)$ in Bedford Basin during February and March 1984 at the 5 depths sampled

pheophorbide a-like became more important, due to the almost complete disappearance of standard pheophorbide a (Fig. 6).

\section{Bloom decline}

In this period (10 to $26 \mathrm{March})$, concentration of pigments increased gradually in the deep layer from 10 to 19 March. Pigment composition at depth resembled that at the surface during the bloom with a predominance of chl $a$, chl $c$ and chl a allomers. The concentration of chl a reached as high as 45 to $60 \%$ of total pigments at 35 and $55 \mathrm{~m}$ (Fig. 5). After 17 March, the re-establishment of stable conditions at the surface (Fig. 1) was not followed by increases in the concentration of the various pigments (Fig. 4). At depth, the surface-type pigments were replaced by the pheophorbide a-like pigment which reached a maximum (1 $\mathrm{n} M$ ) at $35 \mathrm{~m}$ on $22 \mathrm{March}$.

\section{DISCUSSION}

\section{Pigment transformations during the bloom}

\section{Early bloom}

During the early part of the bloom, which was favoured by water column stability (Fig. 1) and increasing solar radiation (Table 1), 3 pigments dominated: chl $a$, chl $c$ and chl a allomers, with chl a representing ca $60 \%$ of total pigments (Fig. 5). The presence of these 2 chlorophylls was expected since the main species present during the bloom were diatoms. The lack of synchronism between $c h l c$ and $c h l$ a may reflect different internal cellular dynamics. Values of the chl $c: c h l a$ ratio oscillated between 0.3 and 0.5 (Fig. 7), close to values obtained for healthy diatom cultures (Jeffrey 1972).

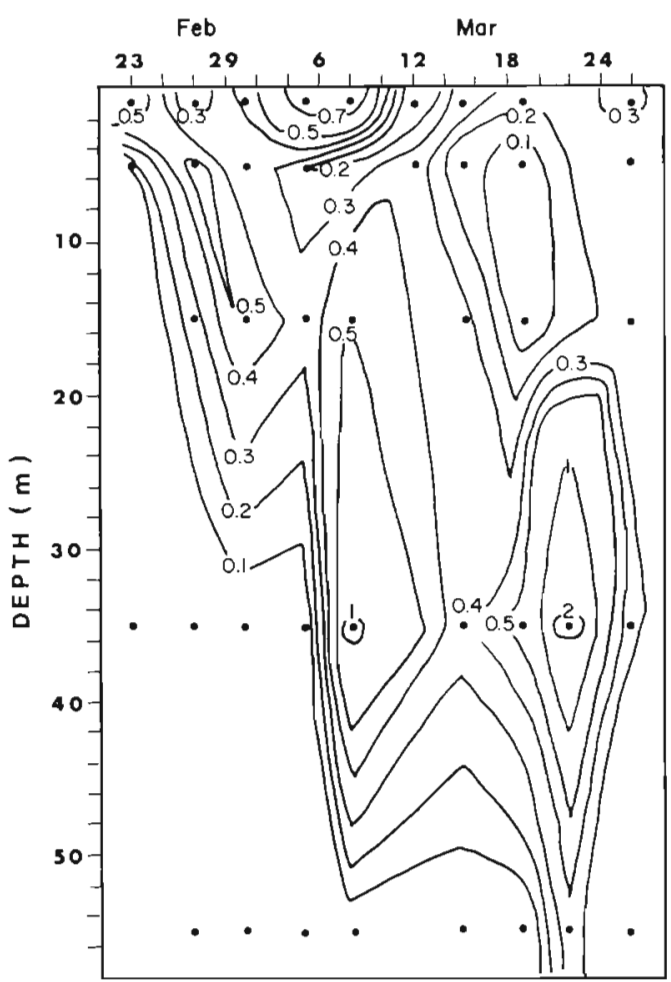

Fig. 7. Chl c: chl a profile during the 1984 spring bloom in Bedford Basin. Both pigment concentrations measured in $\mathrm{n} M$ (molar ratio) 
The presence of chl a allomers early in the bloom is surprising since these pigments are usually associated with senescence and cell lysis (Daley \& Brown 1973, Jensen \& Sakshaug 1973, Hallegraeff \& Jeffrey 1985). They can sometimes be associated with periods of strong algal growth in cultures (Klein 1988, Roy 1988), although at a low level (less than $5 \%$ of total pigments). Their relative proportion in Bedford Basin was larger than culture levels (for Phaeodactylum tricornutum; Roy 1988) and suggests perhaps species-specific reactions or undetermined mechanisms contributing to the presence of this pigment.

Low surface concentrations of pheopigments during this period suggest little grazing activity (Currie 1962, Lorenzen 1967, Shuman \& Lorenzen 1975). The isolated strong value of the pheophorbide a-like pigment at $55 \mathrm{~m}$ on 1 March could be due to fast-sedimenting feces or bottom-resuspension of pheopigment-containing material (Hargrave \& Taguchi 1978).

\section{Late bloom}

During this period, characterized by stable water conditions (Fig. 1) and increasing average solar radiation (Table 1), often-used cellular disruption indicators (chl a allomers, chlorophyllide a) and pheopigments were increasingly observed. The pigment distribution during late bloom can be interpreted on the basis of declining physiological condition and/or resulting from grazing. Chl a alteration products (likely allomers) have, for example, been observed in association with broken and senescent cells and in copepod feces (Hallegraeff \& Jeffrey 1985). Chlorophyllide a can result from cellular senescence (Gowen et al. 1983, Ridout \& Morris 1985), with strong species-specific differences in the chlorophyllase activity (Jeffrey \& Hallegraeff 1987). In some cases, however, there is no relation between chlorophyllide $a$ and senescence (Klein 1988). This pigment can also come from grazing-related dis- ruption of cells (Gieskes \& Kraay 1980). The increase in the chl $c:$ chl a ratio at $1 \mathrm{~m}$ (Fig. 7) can be indicative of cellular senescence (Jeffrey 1974). However, this ratio should be used with caution when grazing is present: varying rates of destruction of these 2 pigments have been reported, for example, in protozoa grazing experiments (Klein et al. 1986).

Indications that the bloom could have been slowing down during this period include low nitrate levels and signs of nutrient stress (increases in the $\mathrm{C}: \mathrm{N}$ and $\mathrm{C}: \mathrm{chl}$ a ratios; Table 2). Previous spring blooms in Bedford Basin were apparently regulated by the supply of nitrate (Conover 1975). Other indications include a strong decrease in chl a (from 75 to $30 \%$ of total pigments at $1 \mathrm{~m} ;$ Fig. 5) and a coincident increase in derivatives of chl $a$ and in chl $c$ : chl $a$. In fact, the inverse trend between chl $a$ and its allomers likely explain why surface maxima of HPLC-measured chl a (1 March) and fluorometrically-measured chl a (8 March) do not coincide (Table 3), although these 2 measures of chl a are not significantly different over the whole study period (Roy 1986). Such a decrease in chl a may reflect the decrease in cellular pigment concentration observed in algal cultures as growth slows down (Prézelin 1982, Klein 1988, Roy 1988)

Indications that grazing could have occurred during this period include increases in pheophytin a and in both forms of pheophorbide $a$. These pigments are generally found in intestinal tracts of grazers and in their fecal material (Jeffrey 1974). Furthermore, previous estimates of grazing during spring in Bedford Basin suggest that 10 to $30 \%$ of daily production can be grazed by mesozooplankton and as much by microzooplankton (Conover \& Mayzaud 1984). Early spring is generally the period of highest seasonal consumption by copepods in this basin (Poulet 1974). High values of pheophytin a compared to pheophorbide a at surface suggest low degradation (fresh feces?) of this pigmentcontaining material (Vernet \& Lorenzen 1987). The increasing importance with depth of the less polar

Table 3. Comparison of chromatographically-measured chl a and chl a-derivatives with fluorometrically-measured chl a (F-chl a) for the $1 \mathrm{~m}$ samples in Bedford Basin in February/March 1984. Units are nM. SUM is the total concentration of (chlorophyllide + chl a allomers + chl a)

\begin{tabular}{|lcccrc|}
\hline Date & Chlorophyllide & Chl a allomers & Chl a & SUM & F-chl a \\
\hline $27 \mathrm{Feb}$ & 0.16 & 0.76 & 6.30 & 7.22 & 6.65 \\
$1 \mathrm{Mar}$ & 0.31 & 1.68 & 9.40 & 11.39 & 7.26 \\
$5 \mathrm{Mar}$ & 0.91 & 2.08 & 5.38 & 8.37 & 7.63 \\
$8 \mathrm{Mar}$ & 0.73 & 4.92 & 4.76 & 10.41 & 8.62 \\
$12 \mathrm{Mar}$ & 0.00 & 1.51 & 3.73 & 5.24 & 3.20 \\
$15 \mathrm{Mar}$ & 0.00 & 1.82 & 2.51 & 2.78 & 2.46 \\
$19 \mathrm{Mar}$ & 0.00 & 0.27 & 0.65 & 0.74 & 0.48 \\
$26 \mathrm{Mar}$ & 0.00 & 0.09 & & & \\
\hline
\end{tabular}


pheophytin and pheophorbide-like forms may be due to differences in grazers and/or in their food, or to photodegradation in surface waters which can transform these pigments into standard pheopigments (Vernet \& Lorenzen 1987). However, photodegradation seems relatively unimportant here: it can be estimated at $10 \%$ daily loss of pheopigments, on first approximation, from SooHoo \& Kiefer's (1982b) model, using temperature and light conditions representative of $1 \mathrm{~m}$ samples in Bedford Basin $\left(0^{\circ} \mathrm{C}, 150 \mu \mathrm{mol}\right.$ photons $\mathrm{m}^{-2} \mathrm{~s}^{-1}$ ). This value is lower than others reported (Welschmeyer \& Lorenzen 1985, Carpenter et al. 1986): this may reflect early spring conditions.

The relatively high specific productivity during this period (Table 2 ) is hard to reconcile with a decelerating bloom. Observed pigment patterns possibly reflect a combination of strong phytoplankton growth with grazing, regenerated nutrients contributing to the continued growth. Chl a derivatives would then result from grazing-related cell disruption and the coincident decrease in chl a and increase in pheopigments would be due to algal cell ingestion by herbivores. Further interpretation of pigment patterns is complicated by the mixed signals refering to grazing and declining physiological condition and the lack of supplementary information concerning zooplankton.

\section{Bloom decline}

Bloom decline was precipitated by a wind event (10 to $15 \mathrm{March}$ ), of the type that can unexpectedly modify the biological characteristics of coastal waters, as previously observed in Bedford Basin (Côté \& Platt 1983). The distinct increase in concentration of pigments below the euphotic zone (10 to $15 \mathrm{~m}$ deep from Secchi readings) from 10 to $19 \mathrm{March}$ is attributed to this event. Increased runoff from the Sackville River at the head of the basin may have contributed to mixing after 15 March, when ice broke up (Water Survey of Canada 1985). Similarity of pigment composition and the presence of the main bloom species at depth further supports the surface origin of these cells. Vertical transport can be considered responsible for displacement of ca $40 \%$ of the chl a present during the bloom period (calculated from average depth-integrated pigment concentrations; Roy 1986). This downward flux is not directly related to bottom sedimentation: Taguchi \& Hargrave (1978) have shown that, for Bedford Basin, daily loss rates of pigments were generally less than $1 \%$ of suspended concentration during the spring period. Decrease in chl a coincident with an increase in the concentration of the pheophorbide a-like pigment at 15,35 and $55 \mathrm{~m}$ (Fig. 4) suggests gradual transformation, likely via grazing, of the surface-type pigments after 15 March. Pheophorbide a derivatives less polar than standard pheophorbide a have been found in copepod feces (Gieskes \& Kraay 1986, Vernet \& Lorenzen 1987), supporting the suggestion of primary consumption. The chl $c$ : chl a values associated with the pheophorbide a-like pigment deep maximum (Figs. 6 and 7) were much higher than those found in algal cells (Jeffrey 1972, Roy 1988). The maximum observed at $35 \mathrm{~m}$ on 22 March could be related to differential destruction of the chlorophylls during grazing (Daley 1973) or grazing by some protozoa which causes faster disappearance of chl a in the dark (Klein et al. 1986). High chl $c$ :chl a values during the bloom decline period could also have been caused by resuspension of bottom detritus (Jeffrey 1974).

After 17 March (Period 3), there is no evidence of renewed algal growth at the surface, despite the stabilization of the water column (Fig. 1). Low light level, including 6 consecutive days of $0.0 \mathrm{~h}$ sunshine (Table 1), can perhaps explain the lack of growth of phytoplankton.

\section{Processes affecting chloropigment distribution}

The various processes suggested to affect pigment distribution in this study were not all measured simultaneously. Their relative importance has been considered using previous studies in this environment.

Grazing seems particularly important in Bedford Basin: as already mentioned, up to $60 \%$ of phytoplankton production could end up as food for meso- and microzooplankton (Conover \& Mayzaud 1984). Other coastal environments also show grazing associated with the spring bloom period (Klein \& Sournia 1987). In terms of pigments, this could bring both transformations (chlorophylls into various pheopigments: Vernet \& Lorenzen 1987) and losses (destruction of pigments: Conover et al. 1986, Klein et al. 1986, Lopez et al. 1988).

Vertical and horizontal transport also influence the observed distribution of pigments. Mixing-related vertical transport removes ca $40 \%$ of chl a from the surface layer. Export out of the basin has been previously estimated at $11 \%$ of the standing stock (Platt \& Conover 1971) and would contribute to pigment loss from surface waters.

Bloom maturation could also affect pigment transformation through changes in the physiological condition of the cells. This may have played a role in the decrease in chl a observed in the first days of March 1984. Pigments are light-sensitive molecules and thus they can further be affected by photodegradation. As previously noted, this process is thought to be of little influence here, due to the early spring conditions. However, if the presence of moribund cells happened to be 


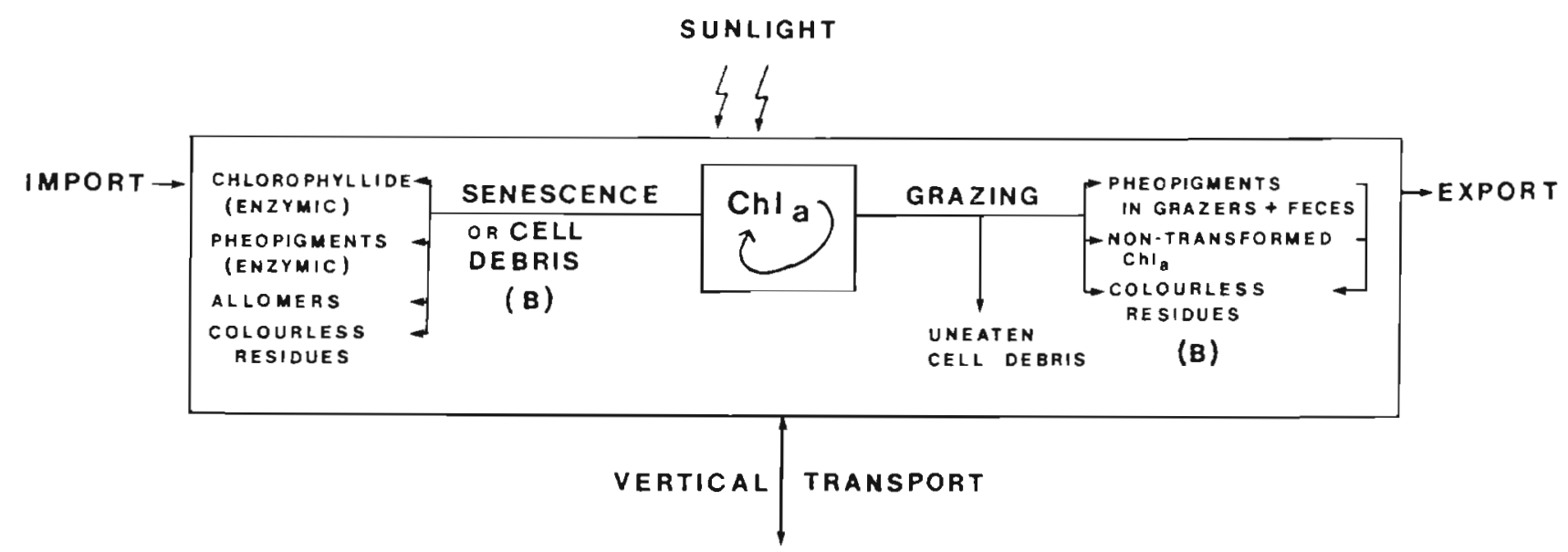

Fig. 8. Conceptual model of the various processes affecting pigment distribution in a water parcel in the euphotic zone. Chl a is chosen as model pigment, originally contained in an algal cell (small box). Curved arrow indicates cell turnover and comprises pigment responses to environmental changes. Large box contains all pigment-containing particles. Physical processes affect all these (shown outside the box). (B): potential bacterial effect

important, photodegradation could become significant as the rate of light destruction of detrital chl a can reach twice that of pheopigments (Carpenter et al. 1986). Thus, the relative importance of moribund versus healthy cells could affect pigment photodegradation through changes in the light-protection efficiency.

Fig. 8 depicts schematically the above-mentioned factors, using chl a as a model pigment and generalizing for a water parcel in the euphotic zone. Both physical processes (horizontal advection, vertical transport) and biological processes (grazing, senescence, cellular turnover) are identified. In Fig. 8, physical processes are illustrated to affect the bulk of pigment-containing particles (large box), composed of algal cells, cell debris, primary consumers and their fecal material. Added complexity is involved since all of these particles will not be affected in a similar way by water movements (e.g. motile zooplankton, or fast-sinking fecal pellets): this would require information on zooplankton distribution and vertical fluxes from sediment traps.

Sunlight influences all pigment-containing particles. This effect can be both positive, favoring algal photosynthesis and growth, and thus pigment accumulation (small box, Fig. 8), or negative, photodegrading pigments. Photodestruction is thought to affect mostly pigment-containing fecal matter and cell debris or moribund cells, healthy cells being generally protected (e.g. by carotenoids). This aspect has received little attention, especially for senescent cells and cell debris

Biological processes affecting pigment distribution that are depicted in Fig. 8 include cellular turnover, covering changes in the cellular pigment content of algal cells related to environmental changes (small box), grazing and senescence. Grazing outcomes on pigments have already been discussed. Fig. 8 specifies additionally that not all chlorophyll is necessarily transformed by consumers and that cell debris can be produced in the grazing process (Roy et al. 1989). Pigments in senescent or broken cells can be affected by catalytic enzymes and oxidative processes activated upon cell disorganisation (Owens \& Falkowski 1982), including the formation of chlorophyllide and pheopigments (via Mg-releasing enzyme), and be more sensitive to photodegradation. Bacterial impact on pigment-bearing particles may also play a mostly undefined role.

Our knowledge of the detailed biological processes illustrated in Fig. 8 is frequently minimal in terms of their impact on pigments. Lack of information concerning pigment fate in detrital cells, fecal material, consumers' digestive system, photodegradation, etc. suggests that we should examine more closely the effects of these processes on the detailed pigment pattern. This will help interpret the accumulating field data on chromatographically-measured pigments and could help identify useful pigment bio-indicators of these processes.

Acknowledgements. This work was supported by grants from the Natural Sciences and Engineering Research Council of Canada to R. O. Fournier and P. J. Wangersky. Scholarships from the Izaak Walton Killam Memorial and the Fonds pour la Formation de Chercheurs et. l'Aide à la Recherche' (FCAR Govermment of Québec) supported the author. Drs B. T. Hargrave, R. Moore, W. W. C. Gieskes, C. C. Parrish and 2 anonymous referees provided helpful comments on the text. The help of the captain and crew of the 'Sigma $T$ ' is gratefully acknowledged.

\section{LITERATURE CITED}

Barrett, J., Jeffrey, S. W (1971). A note on the occurrence of chlorophyllase in marine algae. J. exp. mar. Biol. Ecol. 7 . 255-262 
Billett, D. S. M., Lampitt, R. S., Rice, A. L., Mantoura, R. F. C. (1983). Seasonal sedimentation of phytoplankton to the deep-sea benthos. Nature, Lond. 302: 520-522

Brown, S. R. (1968). Absorption coefficients of chlorophyll derivatives. J. Fish. Res. Bd Can. 25 (3): 523-540

Carpenter, S. R., Elser, M. M., Elser, J. J. (1986). Chlorophyll production, degradation, and sedimentation. Implications of paleolimnology. Limnol. Oceanogr. 31 (1): 112-124

Conover, S. A. M. (1975). Nitrogen utilization during spring blooms of marine phytoplankton in Bedford Basin, Canada. Mar. Biol. 32: 247-261

Conover, R. J., Mayzaud, P. (1984). Utilization of phytoplankton by zooplankton during the spring bloom in a Nova Scotia inlet. Can. J. Fish. aquat. Sci. 41: 232-244

Conover, R. J., Durvasula, R., Roy, S., Wang, R. (1986). Probable loss of chlorophyll-derived pigments during passage through the gut of zooplankton, and some of the consequences. Limnol. Oceanogr. 31 (4): 878-887

Côté, B., Platt, T (1983). Day-to-day variations in the springsummer photosynthetic parameters of coastal marine phytoplankton. Limnol. Oceanogr. 28 (2): 320-344

Currie, R. I. (1962). Pigments in zooplankton faeces. Nature, Lond. 193: 956-957

Daley, R. J. (1973). Experimental characterization of lacustrine chlorophyll diagenesis. II. Bacterial, viral and herbivore grazing effects. Arch. Hydrobiol. 72 (4): 409-439

Daley, R. J., Brown, S. R. (1973). Experimental characterization of lacustrine chlorophyll diagenesis. I. Physiological and environmental effects. Arch. Hydrobiol. 72 (3): 277-304

Daley, R. J., Gray, C. B. J., Brown, S. R. (1973). Reversedphase thin-layer chromatography of chlorophyll derivatives. J. Chromatogr. 76: 175-183

Environment Canada (1984). Monthly meteorological summary, February, March 1984, Halifax-Dartmouth, N.S. (Shearwater A.). Environment Canada, Atmospheric Environment, Ottawa

Fogg, G. E. (1965). Algal cultures and phytoplankton ecology. Univ. of Wisconsin Press

Gieskes, W. W. C., Kraay, G. W. (1980). Primary productivity and phytoplankton pigment measurements in the northern North Sea during FLEX '76. 'Meteor' Forsch.-Ergebn., Reihe A, 22: 105-112

Gieskes, W W. C., Kraay, G. W. (1986). Analysis of phytoplankton pigments by HPLC before, during and after mass occurrence of the microflagellate Corymbellus aureus Green during the spring bloom in the northern North Sea in 1983. Mar. Biol. 92: 45-52

Gowen, R. J., Tett, P., Wood, B. J. B. (1983). Changes in the major dihydroporphyrin planktonic pigments during the spring bloom of phytoplankton in 2 Scottish sea-lochs. J. mar. biol. Ass. U.K. 63: 27-36

Hallegraeff, G. M. (1977). Pigment diversity in freshwater phytoplankton. II. Summer-succession in three Dutch lakes with different trophic characteristics. Int. Revue ges. Hydrobiol. 62 (1): 19-39

Hallegraeff, G. M. (1981). Seasonal study of phytoplankton pigments and species at a coastal station of Sydney: importance of diatoms and nanoplankton. Mar. Biol. 61: $107-118$

Hallegraeff, G. M., Jeffrey, S. W. (1985). Description of new chlorophyll a alteration products in marine phytoplankton. Deep Sea Res. 32: 697-705

Hargrave, B. T., Taguchi, S. (1978). Origin of deposited material sedimented in a marine bay. J. Fish. Res. Bd Can. 35: $1604-1613$

Hitchcock, G. L., Smayda, T. J. (1977). The importance of light in the initiation of the 1972-1973 winter-spring diatom bloom in Narragansett Bay. Limnol. Oceanogr. 22: $126-131$

Holmes, R. W. (1970). The Secchi disk in turbid coastal waters. Limnol. Oceanogr. 15: 688-694

Holm-Hansen, O., Lorenzen, C. J., Holmes, R. W., Strickland, J. D. H. (1965). Fluorometric determination of chlorophyll. J. Cons perm. int Explor Mer 30: 3-15

Jeffrey, S. W (1972). Preparation and some properties of crystalline chlorophyll $c_{1}$ and $c_{2}$ from marine algae. Biochim. Biophys. Acta 279: 15-33

Jeffrey, S. W. (1974). Profiles of photosynthetic pigments in the ocean using thin-layer chromatography. Mar. Biol. 26: $101-110$

Jeffrey, S. W. (1981). An improved thin-layer chromatographic technique for marine phytoplankton pigments. Limnol. Oceanogr. 26: 191-197

Jeffrey, S. W., Hallegraeff, G. M. (1987). Chlorophyllase distribution in ten classes of phytoplankton: a problem for chlorophyll analysis. Mar. Ecol. Prog. Ser. 35: 293-304

Jensen, A., Sakshaug, E. (1973). Studies on the phytoplankton ecology of the Trondheimsfjord. II. Chloroplast pigments in relation to abundance and physiological state of the phytoplankton. J. exp. mar. Biol. Ecol. 11: 137-155

Klein, B. (1988). Variations of pigment content in two benthic diatoms during growth in batch cultures. J. exp. mar. Biol. Ecol, 115: 237-248

Klein, B., Gieskes, W. W. C., Kraay, G. G. (1986). Digestion of chlorophylls and carotenoids by the marine protozoan Oxyrrhis marina studied by h.p.l.c. analysis of algal pigments. J. Plankton Res. 8 (5): 827-836

Klein, B., Sournia, A. (1987). A daily study of the diatom spring bloom at Roscoff (France) in 1985. II. Phytoplankton pigment composition studied by HPLC analysis. Mar. Ecol. Prog. Ser. 37: 265-275

Kobayashi, Y., Maudsley, D. V. (1969). Practical aspects of liquid scintillation counting. Meth. Biochem. Analysis 17: 55-133

Lopez, M. D. G., Huntley, M. E., Sykes, P. F. (1988). Pigment destruction by Calanus pacificus: impact on the estimation of water column fluxes. J. Plankton Res. 10 (4): 715-734

Lorenzen, C. J. (1967). Vertical distribution of chlorophyll and phaeopigments: Baja California. Deep Sea Res. 14: $734-745$

Lorenzen, C. J., Jeffrey, S. W. (1980). Determination of chlorophyll in seawater Unesco Tech. Pap. in Mar. Sci. no. 35

Malone, T C., Falkowski, P. G., Hopkins, T. S., Rowe, G. T., Whitledge, T. E. (1983). Mesoscale response of diatom populations to a wind event in the plume of the Hudson River. Deep Sea Res. 30 (2A): 149-170

Mantoura, R. F. C., Llewellyn, C. C. (1983). The rapid determination of algal chlorophyll and carotenoid pigments and their breakdown products in natural waters by reverse phase high-performance liquid chromatography. Analytica Chim. Acta 151: 297-314

Owens, T. G., Falkowski, P. G. (1982). Enzymatic degradation of chlorophyll a by marine phytoplankton in vitro. Phytochem. 211: 979-984

Parrish, C. C. (1987). Time series of particulate and dissolved lipid classes during spring phytoplankton blooms in Bedford Basin, a marine inlet. Mar. Ecol. Prog. Ser. 35: 129-139

Platt, T., Conover, R. J. (1971). Variability and its effect on the $24 \mathrm{~h}$ chlorophyll budget of a small marine basin. Mar. Biol. 10: $52-65$

Platt, T., Irwin, B., Subba Rao, D. V. (1973). Primary production and nutrient measurement on the spring phytoplankton bloom in the Bedford Basin, 1971. Fish. Res. Bd Can. Tech. Rep. no. 423 
Platt, T., Subba Rao, D. V (1970). Primary production measurements on a natural plankton bloom. J. Fish. Res. Bd Can. $27 \cdot 887-899$

Poulet, S. A. (1974). Seasonal grazing of Pseudocalanus minutus on particles. Mar. Biol. 25: 109-123

Prézelin, B. B. (1982). Effects of light intensity on aging of the dinoflagellate Gonyaulax polyedra. Mar. Biol. 48: 27-35

Ridout, P. S., Morris, R. J. (1985). Short-term variations in the pigment composition of a spring phytoplankton bloom from an enclosed experimental ecosystem. Mar. Biol. 87: $7-11$

Ridout, P. S., Morris, R. J. (1988). Further studies of short-term variation in the pigment composition of a spring phytoplankton bloom. Mar. Biol. 97: 597-602

Riley, G. A. (1943). Physiological aspects of spring diatom flowerings. Bull. Bingham oceanogr Coll. 8 (4): 1-53

Roy, S. (1986). Marine chloropigments: chromatographic measurement in phytoplankton and transformations in algal cultures and a spring bloom event in a marine bay. Ph.D. thesis, Dalhousie University

Roy, S. (1988). Effects of changes in physiological conditions on HPLC-defined chloropigment composition of Phaeodactylum tricornutum (Bohlin) in batch and turbidostat cultures. J. exp. mar. Biol. Ecol. 118: 137-149

Roy, S. Harris, R. P., Poulet, S. A. (1989). Inefficient feeding by Calanus helgolandicus and Temora longicornis on Coscinodiscus wailesii: quantitative estimation using chlorophyll-type pigments and effects on dissolved free amino acids. Mar. Ecol. Prog. Ser. 52: 145-153

Sakshaug, E. (1980). Problems in the methodology of studying phytoplankton. In: Morris, I. (ed.) The physiological ecology of phytoplankton. Univ. of California Press, Berkeley

Shuman, F. R., Lorenzen, C. J. (1975). Quantitative degradation of chlorophyll by a marine herbivore. Limnol. Oceanogr. 20 (4): 580-586

This article was submitted to the editor
Smetacek, V., Von Brockel, K., Zeitschel, B., Zenk, W (1978) Sedimentation of particulate matter during a phytoplankton spring bloom in relation to the hydrographical regime. Mar. Biol. 47: 211-226

Smith, J. C., Platt, T., Harrison, W. G. (198.3). Photoadaptation of carboxylating enzymes and photosynthesis during a spring bloom. Prog. Oceanogr. 12: 425-459

SooHoo, J. B., Kiefer, D. (1982a). Vertical distribution of phaeopigments. I. A simple grazing and photo-oxidative scheme for small particles. Deep Sea Res. 29 (12A): $1539-1551$

SooHoo, J. B., Kiefer, D. (1982b). Vertical distribution of phaeopigments. II. Rates of production and kinetics of photo-oxidation. Deep Sea Res. 29 (12A): 1553-1563

Strickland, J. D. H., Parsons, T R. (1972). A practical handbook of seawater analysis. Bull. Fish. Res. Bd Can. 167

Taguchi, S., Hargrave, B. T (1978). Loss rates of suspended material sedimented in a marine bay. J. Fish. Res. Bd Can. 35: $1614-1620$

Utermöhl, H. (1931). Neue Wege in der quantitativen Erfassung des Planktons (mit besonderer Berücksichtigung des Ultraplanktons). Verh. int. Verein theor. angew. Limnol. 5: $567-596$

Vernet, M., Lorenzen, C. J. (1987). The relative abundance of pheophorbide $a$ and pheophytin a in temperate marine waters. Limnol. Oceanogr. 32 (2): 352-358

Water Survey of Canada (1985). Surface water data, Atlantic provinces. Inland Waters Directorate, Water Resources Branch, Ottawa

Welschmeyer, N. A., Lorenzen, C. J. (1985). Chlorophyll budgets: zooplankton grazing and phytoplankton growth in a temperate fjord and the central Pacific gyres. Limnol. Oceanogr. $30(1): 1-21$

Yentsch, C. S., Menzel, D. W. (1963). A method for the determination of phytoplankton chlorophyll and phaeophytin by fluorescence. Deep Sea Res. 10: 221-231

Manuscript first received: March 18, 1988

Revised version accepted: April 30, 1989 